\title{
Effects of Humic Acid on Millet Growth and Soil Water Preservation under Millet Production with Rainfed Sandy Soil in a Semi- arid Region
}

\author{
Junzhen Mi \\ Oat Scientific and Technical Innovation Team \\ Inner Mongolia Agricultural University \\ Hohhot, Inner Mongolia, 010019, China \\ E-mail:mijunling1206@126.com$$
\text { Jinghui Liu }{ }^{*}
$$ \\ Oat Scientific and Technical Innovation Team \\ Inner Mongolia Agricultural University \\ Hohhot, Inner Mongolia, 010019, China \\ E-mail:mijunling1206@126.com \\ * Corresponding Author
}

\author{
Lingling Zhang \\ Oat Sciencientific and Technial Innovation Team \\ Inner Mongolia Agricultural University \\ Hohhot, Inner Mongolia, 010019, China
}

\author{
Xiaomin Chen \\ Oat Sciencientific and Technial Innovation Team \\ Inner Mongolia Agricultural University \\ Hohhot, Inner Mongolia, 010019, China
}

\begin{abstract}
Effects of using different year of humic acid on millet growth and water and fertilizer use efficiency was studied in a field experiment in a semi-arid and arid region in 2011-2014. Four-year results showed that after using humic acid, the soil moisture content was increased by $0.20 \%-40.41 \%$ over that of $\mathrm{CK}$, and it mainly affected soil moisture content of $0-40 \mathrm{~cm}$ soil layer, the differences decreased with soil layer depth increasing; plant height and dry matter weight were increased by $2.19 \%-15.06 \%$ and $\mathbf{0 . 5 9 \% - 2 3 6 . 8 1 \%}$ respectively over that of $\mathrm{CK}$; grain and biological yield were significantly increased by $1.09 \%$ $14.76 \%$ and $0-25.27 \%$ over that of CK, and the effect of current year with the continuous use ofuse of humic acid is best, and the fourth-year effect of treatment only with the use ofuse of one-year humic acid had no significant differences compared with CK; water and fertilizer was similar to the variation of yield. In a word, the use of humic acid could improve the condition of soil water and fertilizer, make full use of limit water resource, increase yield, thus it could increase water and fertilizer use efficiency, and reduce environmental pollution, treatment by continuously using 4year humic acid was best.
\end{abstract}

Keywords- Humic Acid; Soil Moisture; Millet; Yield; Water and Fertilizer Use Efficiency

\section{INTRODUCTION}

Water is essential condition to plants survived ${ }^{[1]}$. Agriculture has a central role in ensuring the food security and welfare of 1.3 billion people ${ }^{[2]}$. At present and more so in the future, irrigated agriculture will take place under water scarcity ${ }^{[3]}$.Cultivated area is $1.97 \times 10^{15} \mathrm{hm}^{2}$ in the whole world, dry farming area has about $42.9 \%$ of all cultivated area, dry farming area accounts for about $50 \%$ of farm area in China. Moreover, the region along the Great Wall belongs to arid and semiarid area, local agricultural production mainly depend on the rainfall. Soil in this area are characterized by low water-holding capacity and excessive evaporation and irrigation water below the root zone, leading to poor water and fertilizer use efficiency by plants grown on them. Seed germination and plant development are critically restricted because of low soil moisture content. The efficiency of the use of limit rain and irrigation water by plants is of great importance in semiarid and arid regions ${ }^{[4-5]}$, where shortage of water is frequently experienced and water is often the limiting factor determining the size of the cultivated area. Therefore, the increased water-use efficiency (WUE) should be a key issue for research.

In modern agriculture, water-saving materials are used to enhance soil moisture. They have been reported that water-saving materials are capable of retain ing water up to 500 times of their weight. They can build an additional water reservoir for the plant-soil. Therefore, when it encounters the drought, it can reduce the stress in plants. The use of superabsorbent polymers significantly increase plant height, stem diameter, leaf area, biomass accumulation and relative water content as well as yield ${ }^{[6-}$ ${ }^{8]}$. Natural compound have been reported as amendment for soil to modify soil environment, and improve cation exchange capacity (CEC) to decrease nitrogen leaching and to increase fertilizer recovery ${ }^{[9]}$. Humic acid is a kind of natural compounds. The studies showed that using humic acid doesn't create any complication for human beings, plants, soil and environment. The humic acid distributed widely in Inner Mongolia, but it still doesn't systematically study on the application of farmland. Therefore, the main objective of this study was to evaluate the long-term and accumulation effectiveness of humic acid for millet production in a drought affected field. 


\section{MATERIALS AND METHODS}

\section{A. Sites description}

The experimental field was located in Yijianfang village $\left(111^{\circ} 39^{\prime} \mathrm{E}, \quad 39^{\circ} 57^{\prime} \mathrm{N}\right)$ of Qingshuihe County, Hohhot, Inner Mongolia, China. It belongs to Loess Hilly gully region, which is typical, and hilly mountain accounts for more than $90 \%$. The average elevation of mountains is $1373.6 \mathrm{~m}$, the mean annual temperature is $7.1^{\circ} \mathrm{C}$, the accumulated temperature $\geq 10{ }^{\circ} \mathrm{C}$ is $2370.2{ }^{\circ} \mathrm{C}$, frost-free period is around $140 \mathrm{~d}$, annual sunshine hours is about $2914 \mathrm{~h}$, the average number of windy day (the instantaneous speed is $17 \mathrm{~m} / \mathrm{s}$ ) is around $19 \mathrm{~d}$, the total annual solar radiant is about $570.6 \mathrm{~kJ} / \mathrm{cm}^{2}$, during crop growth period average annual evaporation is $2577 \mathrm{~mm}$, and annual rainfall is about $365 \mathrm{~mm}$, being concentrated mainly in July. Table 1 shows monthly rainfall and at the experimental site over the three-yearstudy. Although there was a difference in rainfall distribution over the growing season, millet growing period 2011 received $193.8 \mathrm{~mm}$ least rainfall a mong 2011, 2012, 2013 and 2014(Table1). It is semi-arid region of mid-temperate zone with continental monsoon climate. The soil is loess, and organic matter is $10.96 \mathrm{~g} \cdot \mathrm{kg}^{-1}$, total nitrogen is $0.49 \mathrm{~g} \cdot \mathrm{kg}^{-1}$, total phosphorus is $0.43 \mathrm{~g} \cdot \mathrm{kg}^{-1}$, available nitrogen is 35.10 $\mathrm{mg} \cdot \mathrm{kg}^{-1}$, available phosphorus is $4.55 \mathrm{mg} \cdot \mathrm{kg}^{-1}$ and available potassiumis $118.90 \mathrm{mg} \cdot \mathrm{kg}^{-1}$.

TABLE II. MONTHLY MEAN RAINFALL OVER FOUR-YEAR TRIAL EXPERIMENT（MM）

\begin{tabular}{ccccc}
\hline \multirow{2}{*}{ Months } & \multicolumn{4}{c}{ Years } \\
\cline { 2 - 5 } & 2011 & 2012 & 2013 & 2014 \\
\hline April & 15.0 & 18.5 & 5.1 & 44 \\
May & 16.0 & 26.1 & 23.8 & 35.3 \\
June & 22.2 & 60.7 & 80.1 & 78.5 \\
July & 25.6 & 144.4 & 213.8 & 77.9 \\
August & 83.0 & 55.1 & 53.6 & 106.5 \\
September & 32.0 & 49.6 & 28.5 & 91.3 \\
\hline
\end{tabular}

\section{B. Experimental materials}

Experimental crop: Millet.

\section{Experimental design}

TABLE II. EXPERIMENTAL DESIGN

\begin{tabular}{|c|c|c|c|}
\hline $\begin{array}{c}\text { Trea } \\
\text { tmen } \\
\text { t }\end{array}$ & $\begin{array}{c}\text { Experim } \\
\text { ental } \\
\text { material }\end{array}$ & $\begin{array}{c}\text { Applicati } \\
\text { on } \\
\text { amount }\end{array}$ & Application time \\
\hline CK & - & - & - \\
\cline { 1 - 1 } T1 & & & Only using one year(Applying into the \\
soil in 2011)
\end{tabular}

Experimental design was presented Table2.This experiment was a randomized complete block (RCB) factorial design with three replications; each treatment occupied a plot area of $4 \mathrm{~m} \times 5 \mathrm{~m}$. Seeds of Millet were sown at the beginning of May and harvested in the middle of September during among four trials (2011, 2012, 2013 and 2014). Row spacing was $25 \mathrm{~cm}$, seeding depth was 3$5 \mathrm{~cm}$, and the planting density was $300000-450000$ plants per hectare. Humic acid was spread in the surface of land equably, and then incorporated into the soil by cultivating. Field management during whole growth period was according to the local farmers. DAP (225 $\mathrm{kg} \cdot \mathrm{hm}-2)$ and urea $(50 \mathrm{~kg} \cdot \mathrm{hm}-2)$ were applied as base fertilizer at planting, and urea $(75 \mathrm{~kg} \cdot \mathrm{hm}-2)$ was applied as topdressing at the crop jointing stage.

\section{Field and laboratory measurements}

Soil bulk density was measured at different growing stages. A pit was excavated with ledges at depths of 0-10, 10-20, 20-40, 40-60, 60-80, and 80-100 cm. A $10 \mathrm{~cm}$ diameter by $5 \mathrm{~cm}$ cutting ring was inserted to remove soil samples for bulk density measurements.

Soil moisture was periodically measured by the depth and time variation with gravimetric method. Soil samples were retrieved manually with a soil auger, at depths of 0 $10,10-20,20-40,40-60,60-80$, and $80-100 \mathrm{~cm}$ in the growth period after sowing. The samples were packed in aluminum boxes and oven-dried at $105^{\circ} \mathrm{C}$ until constant weight.

Plant height: 20 plants millet plants whose growth were uniform from every experiment field plot was selected at each growth stage.

Dry matter weight: 10 plants millet plants growth of which was uniform from every experiment field plot were selected, which were taken to the laboratory at each growth stage. At first, they were put in the oven whose temperature was $105^{\circ} \mathrm{C}$ for 30 minutes, then they were dried under $85^{\circ} \mathrm{C}$ until their weight was constant. 
Yield was measured at maturity. A $1 \mathrm{~m}^{2}$ area of each plot was harvested by hand for grain yield and biological yield.

\section{E. Data analysis}

Soil water storage $(h)$ was calculated by Equation (1): $h=H s \times w \times d \times 10(1)$

Where $H s$ is soil depth $(\mathrm{cm}), w$ is gravimetric soil moisture content, $d$ is soil bulk density.

Field water consumption (ET) was calculated by Equation (2):

$$
E T=p+\Delta h+m(2)
$$

Where $p$ is the total precipitation during growing season $(\mathrm{mm}), \Delta h$ is gravimetric soil moisture content, $\Delta h$ is the variation of soil water storage during growing season $(\mathrm{mm}), m$ is water added by irrigation during the period $(\mathrm{mm})$. The experimental field was flat, the groundwater table was deep, depth of soil layer was thick, and soil texture was uniform, so the field water consumption mainly was related to effective rainfall, soil water storage and water added by irrigation during the period.

Water use efficiency (WUE) was calculated by Equation (3):

$$
W U E=B / E T(3)
$$

Where $B\left(\mathrm{~kg} \cdot \mathrm{h} \mathrm{m}^{-2}\right)$ is the biological yie ld of millet, and $E T(\mathrm{~mm})$ is the total whole growing season field water consumption determined from Equation (2).

Fertilizer use efficiency $(Y)$ was calculated by Equation (4):

$$
Y=A / T(4){ }^{[10]}
$$

Where $A\left(\mathrm{~kg} \cdot \mathrm{hm}^{-2}\right)$ is the grain yield of millet, and $T$ $(\mathrm{mm})$ is the total whole growing season using fertilizer amount.

An analysis of variance (ANOVA) was performed using SAS Ver. 9.0 software. Tests of significant use the least significant difference (LSD) at $P \leq 0.05$.

\section{RESULTS}

\section{A. Soilmoisture content}

Vertical variation of soil moisture content with humic acid by the mean of different sampling times in 2011-2014 was presented in Fig. 1.Humic acid had a different effect on soil moisture in different soil layers, the differences were maximum at all treatments in $10-20 \mathrm{~cm}$ soil layer. The trend of soil mo is ture was increasing, then decreasing, and increasing again, however, in 2011,the trend of soil moisture was increasing, and then decreasing. Except 2012, humic acid could increasing soil moisture at all soil layers, compared with CK, soil moisture content in 2011 and 2014 was increased by $3.63 \%-7.58 \%$ and 0.98 $40.41 \%$ respectively; in 2012 , soil mo isture content of 0 $80 \mathrm{~cm}$ soil layers was increased by $4.66 \%-21.34 \%$, it had a instable effect on soil moisture content at $80-100 \mathrm{~cm}$ soil layer, T2 had a certain decrease; in 2013,

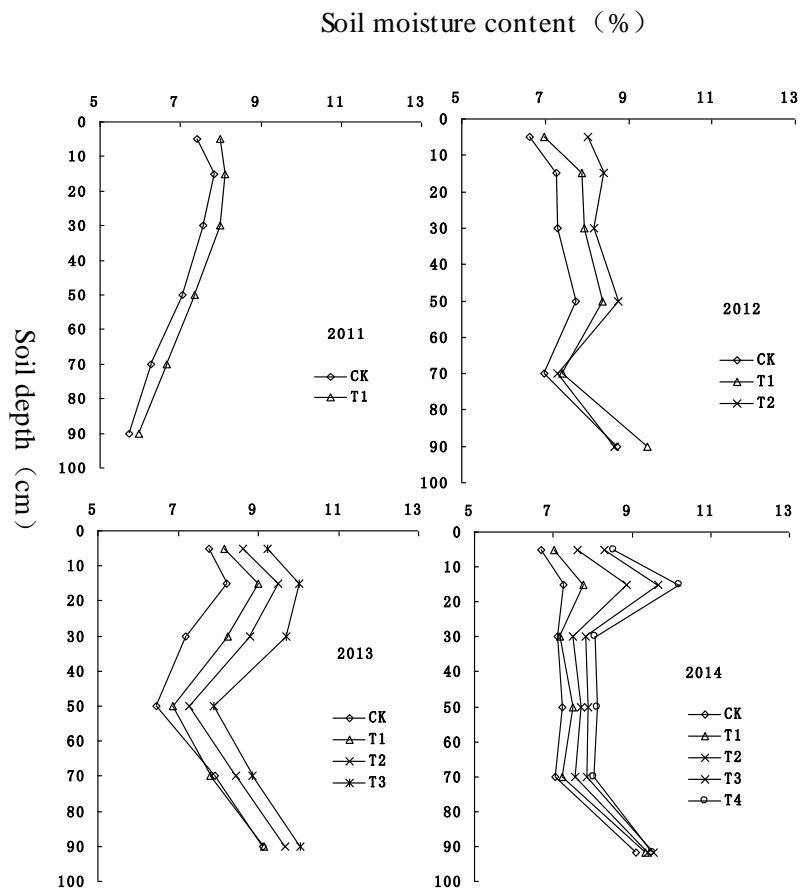

Figure 1. Vertical variation of soil moisture content with humic acid by the mean of different sampling times in 2011-2014

soil moisture content of $0-60 \mathrm{~cm}$ soil layers was increased by $4.83 \%-34.87 \%$, it had a instable effect on soil mo is ture content at $60-100 \mathrm{~cm}$ soil layer. Therefore, humic acid mainly affected on distribution of soil moisture at 0 $40 \mathrm{~cm}$ arable layer, this was closely related to application depth and soil type, the effect of all treatments with humic acid on the mean of soil mo isture content in 2011-2014 showed: it was $\mathrm{T} 1>\mathrm{CK}$ in $2011, \mathrm{~T} 2>\mathrm{T} 1>\mathrm{CK}$ in 2012,T3>T2> T1> CK in 2013 andT4>T $3>\mathrm{T} 2>\mathrm{T} 1>\mathrm{CK}$ in 2014.In short, the effect of current year with the continuous use of humic acid is best, and the fourth-year effect of treatment only with the use of one-year humic acid had no significant differences compared with CK.

\section{B. Millet plant height}



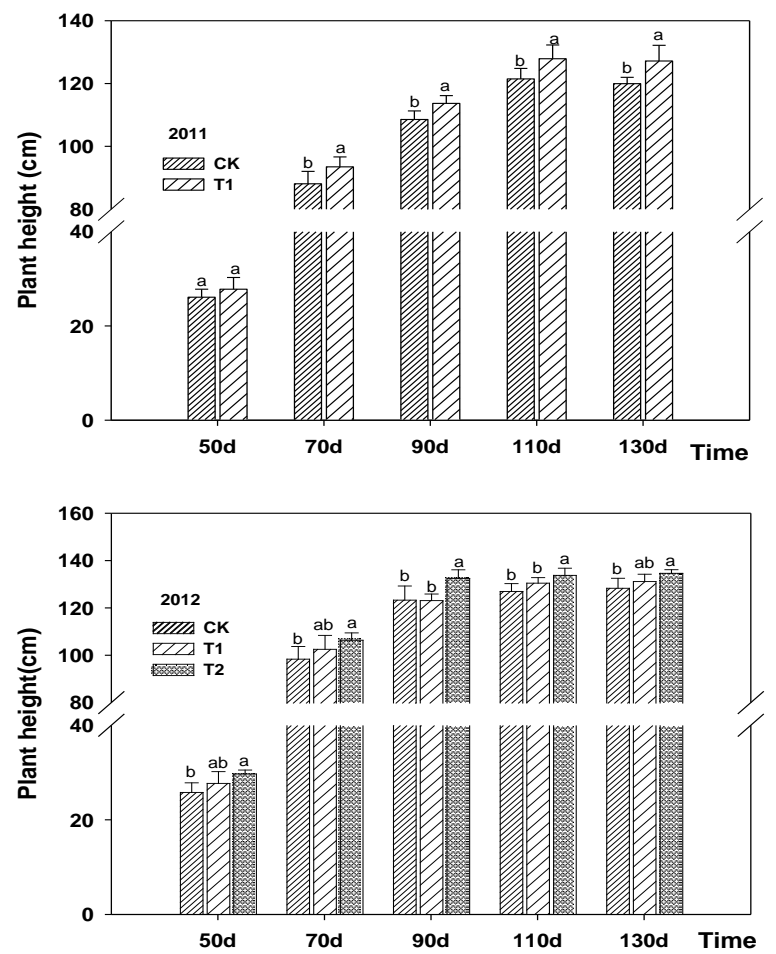

Figure 2. The variation of millet plant height with humic acid in 2011-2012

The effects of humic acid on plant height over the growing season were presented in Fig. 2 and Fig. 3. In 2011, at 50d after sowing, treatment with humic acid had no significant effect $(\mathrm{P}<0.05)$ on plant height, this was because effective rainfall was less, and the drought was serious; at $70 \mathrm{~d}, 90 \mathrm{~d}, 110 \mathrm{~d}$ and $130 \mathrm{~d}$ after sowing, millet plant height with humic acid was significantly higher than that of CK, it increased by $4.74 \%-6.51 \%$ respectively over that of CK; in 2012 - 2014, in nutrition stage, millet plant height rapidly grew, the increase became slow in reproductive stage, except $\mathrm{T} 1$, other treatments with humic
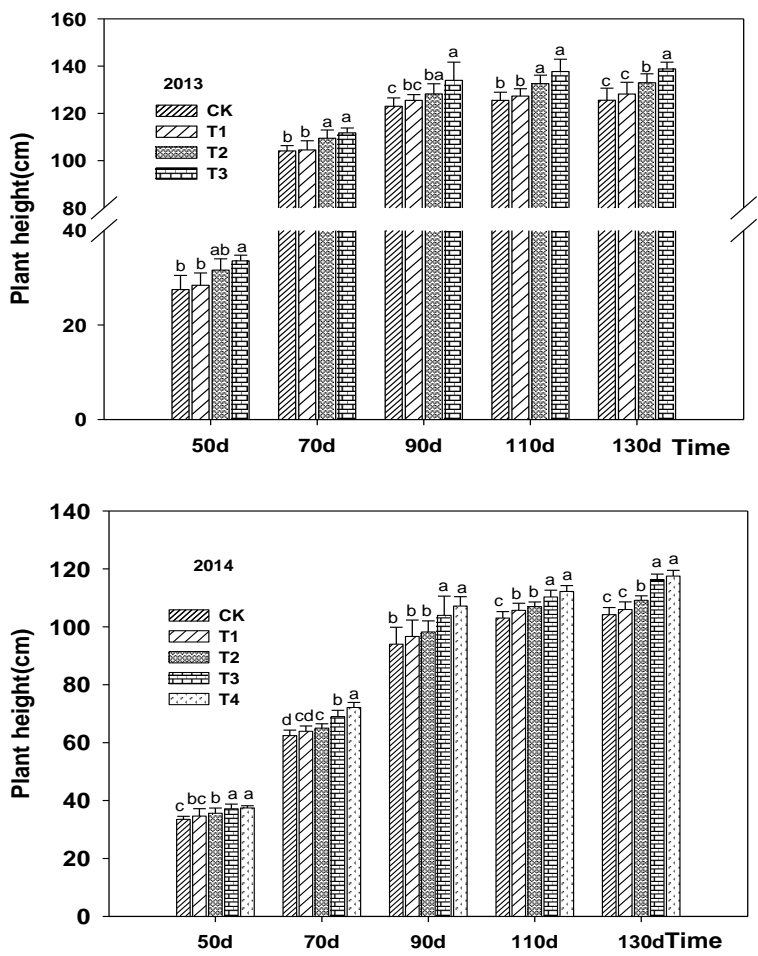

Figure 3. The variation of millet plant height with humic acid in 2013-2014

acid all significantly increased the plant height of millet, they increased by $2.19 \%-15.06 \%, 1.47 \%-22.11 \%, 1.69 \%$ $15.53 \%$ respectively over that of CK. Thus, under the drought condition, humic acid as water-saving material could play its maximum degree water-retaining role.The effect of humic acid on millet growth at early stage was larger, so humic acid laid a foundation for millet latter growth. The effect of all treatments with humic acid on millet plant height in 2011-2014 showed: it was T1>CK in 2011, T2>T1>CK in 2012, T3>T2> T1>CK in 2013 and $\mathrm{T} 4>\mathrm{T} 3>\mathrm{T} 2>\mathrm{T} 1>\mathrm{CK}$ in 2014.

TABLE III. THE VARIATION OF MILLET DRY MATTER WEIGHT WITH HUMIC ACID IN 2011-2014

\begin{tabular}{|c|c|c|c|c|c|c|}
\hline \multirow{2}{*}{ Year } & \multirow{2}{*}{ Treatment } & \multicolumn{5}{|c|}{ Time } \\
\hline & & $50 d$ & $70 d$ & $90 d$ & $110 d$ & $130 d$ \\
\hline \multirow{2}{*}{2011} & CK & $0.22 \pm 0.02 \mathrm{a}$ & $12.11 \pm 0.44 b$ & $20.66 \pm 1.27 b$ & $34.97 \pm 0.75 b$ & $61.06 \pm 2.22 \mathrm{a}$ \\
\hline & $\mathrm{T} 1$ & $0.24 \pm 0.02 \mathrm{a}$ & $17.2 \pm 0.63 \mathrm{a}$ & $25.52 \pm 1.55 \mathrm{a}$ & $42.46 \pm 1.55 \mathrm{a}$ & $69.47 \pm 2.53 \mathrm{a}$ \\
\hline \multirow{3}{*}{2012} & CK & $0.2 \pm 0.04 b$ & $13.58 \pm 0.50 \mathrm{c}$ & $54.81 \pm 1.20 \mathrm{c}$ & $66.09 \pm 2.41 \mathrm{~b}$ & $97.67 \pm 3.56 b$ \\
\hline & $\mathrm{T} 1$ & $0.25 \pm 0.02 b$ & $16.42 \pm 0.60 \mathrm{~b}$ & $61.27 \pm 2.23 b$ & $74.21 \pm 2.70 \mathrm{a}$ & $104.07 \pm 3.79 b$ \\
\hline & $\mathrm{T} 2$ & $0.33 \pm 0.02 \mathrm{a}$ & $24.5 \pm 0.89 a$ & $70.16 \pm 2.56 \mathrm{a}$ & $76.11 \pm 2.77 \mathrm{a}$ & $112.09 \pm 4.08 \mathrm{a}$ \\
\hline \multirow{4}{*}{2013} & $\mathrm{CK}$ & $0.30 \pm 0.03 c$ & $5.41 \pm 0.20 \mathrm{~d}$ & $40.56 \pm 1.48 c$ & $58.57 \pm 2.13 b$ & $80.03 \pm 2.91 \mathrm{c}$ \\
\hline & $\mathrm{T} 1$ & $0.32 \pm 0.01 \mathrm{c}$ & $6.07 \pm 0.22 \mathrm{c}$ & $40.80 \pm 1.49 c$ & $62.27 \pm 2.27 \mathrm{ab}$ & $85.73 \pm 3.12 b c$ \\
\hline & $\mathrm{T} 2$ & $0.39 \pm 0.01 \mathrm{~b}$ & $8.21 \pm 0.30 b$ & $45.91 \pm 1.67 b$ & $66.20 \pm 2.41 \mathrm{a}$ & $91.70 \pm 3.34 \mathrm{ab}$ \\
\hline & $\mathrm{T} 3$ & $0.45 \pm 0.05 a$ & $10.01 \pm 0.36 \mathrm{a}$ & $50.30 \pm 1.83 a$ & $66.60 \pm 2.43 \mathrm{a}$ & $97.30 \pm 3.54 \mathrm{a}$ \\
\hline \multirow{5}{*}{2014} & $\mathrm{CK}$ & $0.23 \pm 0.03 \mathrm{~d}$ & $8.81 \pm 0.32 \mathrm{~d}$ & $18.32 \pm 0.67 c$ & $54.61 \pm 1.99 \mathrm{~d}$ & $65.10 \pm 2.37 c$ \\
\hline & $\mathrm{T} 1$ & $0.24 \pm 0.02 \mathrm{~d}$ & $9.8 \pm 0.36 \mathrm{c}$ & $18.59 \pm 0.68 \mathrm{c}$ & $60.29 \pm 2.20 \mathrm{c}$ & $65.72 \pm 2.39 c$ \\
\hline & $\mathrm{T} 2$ & $0.42 \pm 0.07 \mathrm{c}$ & $10.29 \pm 0.37 b c$ & $20.20 \pm 0.74 b$ & $65.21 \pm 2.38 b$ & $73.90 \pm 2.69 b$ \\
\hline & $\mathrm{T} 3$ & $0.63 \pm 0.09 b$ & $10.63 \pm 0.39 b$ & $21.91 \pm 0.80 \mathrm{a}$ & $66.60 \pm 2.43 \mathrm{ab}$ & $80.38 \pm 2.93 \mathrm{a}$ \\
\hline & $\mathrm{T} 4$ & $0.77 \pm 0.06 \mathrm{a}$ & $13.78 \pm 0.50 \mathrm{a}$ & $21.97 \pm 0.80 \mathrm{a}$ & $69.42 \pm 2.53 \mathrm{a}$ & $85.15 \pm 3.10 \mathrm{a}$ \\
\hline
\end{tabular}




\section{Dry matter accumulation}

Dry matter weight above-ground in 2011- 2014 is given in Table3.Humic acid could increase dry matter weight of millet in different degree. At 50d after sowing, the differences were not significant $(\mathrm{P}<0.05)$ between $\mathrm{T} 1$ with humic acid and $\mathrm{CK}$, other treatments all significantly $(\mathrm{P}<0.05)$ increased millet dry matter weight above-ground;

at $70 \mathrm{~d}, 90 \mathrm{~d}, 110 \mathrm{~d}, 130 \mathrm{~d}$ after sowing, treatments with humic acid (except T1 in 2012-2014) all significantly $(\mathrm{P}<0.05)$ increased millet dry matter weight above-ground. In 2011, treatments with humic acid could increase millet dry matter weight above-ground at $50 \mathrm{~d}, 70 \mathrm{~d}, 90 \mathrm{~d}, 110 \mathrm{~d}$, $130 \mathrm{~d}$ after sowing, they increased by $9.23 \%, 42.03 \%$ 、 $23.56 \%, 21.43 \%$ and $13.76 \%$ compared with CK; they increased by $6.40 \%-48.57 \%, 12.27 \%-85.16 \%, 0.59 \%-$ $24.02 \%, 6.32 \%-13.71 \%, 7.13 \%-21.57 \%$ over that of CK

in 2013; increased by $5.80 \%-236.81 \%, 11.24 \%-56.40 \%$, $10.21 \%-19.88 \%, 10.41 \%-27.12 \%$ and $0.94 \%-30.79 \%$ over that of CK. The effect of humic acid on millet dry matter weight above-ground was similar to millet plant height. All showed that effect of current year with the continuous use of humic acid is the best, and the fourth-year effect of treatment only with the use of one-year humic acid had no significant differences compared with $\mathrm{CK}$. increased by $8.04 \%, 6.60 \%-10.48 \%, 5.89 \%-14.35 \%$ and $1.09 \%-14.76 \%$ compared with CK. From biological yield analysis, treatments with humic acid (except T1 in 2013 and T1 and T2 in 2014) were significantly higher than CK. Compared with $\mathrm{CK}$, treatments with humic acid increased by $10.43 \%, 9.74 \%-18.38 \%, 4.96 \%-25.27 \%$ and $0.00 \%$ $6.53 \%$ in 2011-2014. For results of yield in 2011-2014, the yield was stable in 2012 and 2013, the yield in 2011 was a half of yield in 2012-2013, and this was because the rainfall was less in 2011, which was only $193.8 \mathrm{~mm}$, and it was half of that in 2012-2013; while the rainfall is equal to that of last two years, but yield was lower than that of last two years, this was due to the hailstorm at booting stage, it affected the millet's late growth. Due to the improvement effect of humic acid, finally treatments with humic acid had yield-increasing effect. All treatments with humic acid showed that effects of current year with the continuous use of humic acid is best, and the fourth-year effect of treatment only with the use of one-year humic acid had no significant differences compared with CK. This is due to accumulative effect of humic acid, and decomposition effect in soil with using time.

TABLE IV. THE VARIATION OF GRAIN AND BIOLOGICAL YIELD WITH HUMIC ACID IN 2011-2014

\begin{tabular}{|c|c|c|c|c|c|}
\hline Year & Treatment & Grain yield $\left(\mathrm{kg} \cdot \mathrm{hm}^{-1}\right)$ & $\begin{array}{c}\text { Increase over } \\
\text { CK }(\%)\end{array}$ & Biological yield $\left(\mathrm{kg} \cdot \mathrm{hm}^{-1}\right)$ & $\begin{array}{c}\text { Increase over } \\
\mathbf{C K}(\%)\end{array}$ \\
\hline \multirow{2}{*}{2011} & CK & $2044.19 \pm 51.62 b$ & - & $11467.40 \pm 289.56 \mathrm{~b}$ & - \\
\hline & $\mathrm{T} 1$ & $2193.76 \pm 55.39 \mathrm{a}$ & 8.04 & $12664.00 \pm 319.77 \mathrm{a}$ & 10.43 \\
\hline \multirow{3}{*}{2012} & $\mathrm{CK}$ & $5235.02 \pm 132.19 \mathrm{~b}$ & - & $21987.49 \pm 555.19 \mathrm{c}$ & - \\
\hline & $\mathrm{T} 1$ & $5580.67 \pm 140.91 \mathrm{a}$ & 6.6 & $22136.32 \pm 609.28 b$ & 9.74 \\
\hline & $\mathrm{T} 2$ & $5783.56 \pm 146.04 \mathrm{a}$ & 10.48 & $26027.75 \pm 657.21 \mathrm{a}$ & 18.38 \\
\hline \multirow{4}{*}{2013} & CK & $5135.40 \pm 129.67 \mathrm{c}$ & - & $21439.05 \pm 541.34 \mathrm{c}$ & - \\
\hline & $\mathrm{T} 1$ & $5401.43 \pm 136.39 b$ & 5.89 & $21506.02 \pm 568.20 \mathrm{c}$ & 4.96 \\
\hline & $\mathrm{T} 2$ & $5644.53 \pm 142.53 \mathrm{ab}$ & 10.65 & $24563.87 \pm 620.24 b$ & 14.58 \\
\hline & T3 & $5832.91 \pm 147.28 \mathrm{a}$ & 14.35 & $26856.26 \pm 678.13 a$ & 25.27 \\
\hline \multirow{5}{*}{2014} & CK & $4420.34 \pm 111.61 b$ & - & $19095.71 \pm 482.17 \mathrm{~b}$ & - \\
\hline & $\mathrm{T} 1$ & $4438.49 \pm 112.07 b$ & 1.09 & $19095.71 \pm 482.17 \mathrm{~b}$ & 0 \\
\hline & $\mathrm{T} 2$ & $4629.34 \pm 116.89 b$ & 5.43 & $19444.72 \pm 490.98 \mathrm{ab}$ & 1.83 \\
\hline & $\mathrm{T} 3$ & $4907.75 \pm 123.92 \mathrm{a}$ & 11.77 & $20192.60 \pm 509.87 \mathrm{a}$ & 5.74 \\
\hline & $\mathrm{T} 4$ & $5038.98 \pm 127.24 a$ & 14.76 & $20342.17 \pm 513.65 \mathrm{a}$ & 6.53 \\
\hline
\end{tabular}

\section{Millet yield}

Yield was regarded as an important index of evaluating agricultural production. Humic acid had yieldincreasing effect in different degree (Table 4).The differences were not significant $(\mathrm{P}<0.05)$ among T1, T2 and CK in 2014, others all were significantly higher than that of CK. For grain yield, treatments with humic acid 

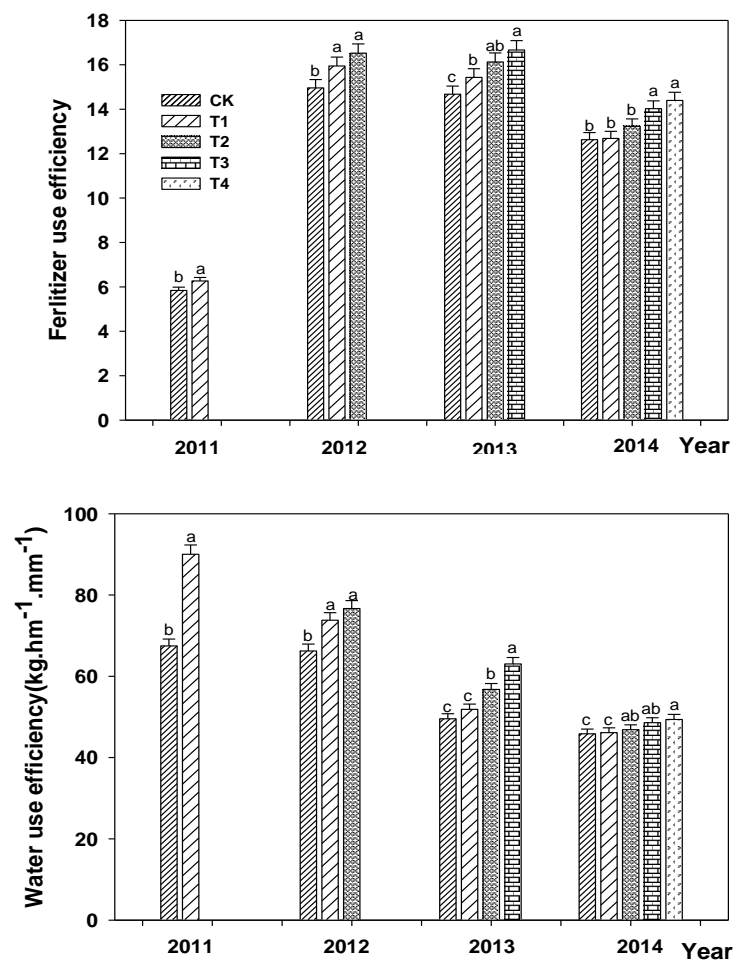

Figure 4. Water and fertilizer use efficiency of millet with humic acid in 2011-2014

\section{E. Water and fertilizer use efficiency}

Humic acid significantly $(\mathrm{P}<0.05)$ improved water and fertilizer use efficiency in 2011-2014 (Fig. 4). Treatment with humic acid significantly $(\mathrm{P}<0.05)$ increased water and fertilizer use efficiency in 2011 , it increased by $33.44 \%$ and $7.32 \%$ respectively over that of CK; in 2011, T1 significantly $(\mathrm{P}<0.05)$ increased water and fertilizer use efficiency, compared with CK, it increased by $33.44 \%$ and $7.32 \%$; in 2012, treatments with humic acid significantly $(\mathrm{P}<0.05)$ increased water and fertilizer use efficiency. However, the differences were not significant between $\mathrm{T} 1$ and $\mathrm{T} 2$, water and fertilizer use efficiency in $\mathrm{T} 1$ and $\mathrm{T} 2$ were increased by $11.39 \%-15.77 \%$ and $6.60 \%-$ $10.48 \%$ respectively over that of CK; in 2013 , except the fertilizer use efficiency in $\mathrm{T} 1$, other treatments were significantly $(\mathrm{P}<0.05)$ higher than $\mathrm{CK}$, water and fertilizer use efficiency in $\mathrm{T} 1, \mathrm{~T} 2$ and $\mathrm{T} 3$ were increased by $4.67 \%$ $27.24 \%$ and $5.18 \%-13.58 \%$ over that of CK; in 2014, except water use efficiency in T1,T2 and fertilizer use efficiency in $\mathrm{T} 1$, other treatments were significantly $(\mathrm{P}<0.05)$ higher than $\mathrm{CK}$, water and fertilizer use efficiency in treatments with humic acid were increased by $0.65 \%-7.71 \%$ and $0.41 \%-14.00 \%$ over that of CK. In four-year, effects of humic acid on water and fertilizer use efficiency of millet showed: effect of current year with the continuous use of humic acid is best, and the fourth-year effect of treatment only with the use of one-year humic acid had no significant differences compared with CK. Therefore, humic acid could increase water and fertilizer use efficiency, reduce soil and water loss, and improve the condition of soil moisture and fertilizer, it helped to make full use of water resource in this region, and improve agroecological environment. Meanwhile, it provided theoretical basis for high yield cultivation of millet in this region.

\section{CONCLUSION}

1) After using the humic acid, it significantly affected the soil moisture in $0-60 \mathrm{~cm}$ soil layers, this is because humic acid could inhibit the loss of water, improve soil water environment, and had the effect of soil water storage and preservation. Under $60 \mathrm{~cm}$ soil layers, the effect of humic acid on it was instable, the differences weren't significant among treatments, and this was due to soil type, application methods and application depth.

2) Xuyu Wang and Rixin Wang ${ }^{[9]}$ found that the ratio of humic acid and SAP could promote the growth of lettuce, plant height significantly increased over $20.63 \%$ $58.75 \%$, and the yield significantly increased over $38.4 \%$ $61.3 \%$. The data have shown that humic acid could improve soil moisture environment, increase available water and fertilizer in soil and promote the growth of millet, plant height, dry matter weight above ground, grain and biological yield were significantly increased by $2.19 \%-15.06 \%, 0.59 \%-236.81 \%$ and $1.09 \%-14.76 \%$, 0 $25.27 \%$.

3) Humic acid can reduce water consumption and fertilizer loss, and increase crop yield, therefore, it can increase water and fertilizer use efficiency of crop. In different years, the effect of current year with humic acid is best, and yield is highest among treatments; the fourthyear effect of treatment only with the use of one-year humic acid has no significant differences compared with CK.

In order to further study the long-term and accumulation effects of humic acid on physical and chemical properties, it is necessary to develop a more complete understanding of the long-term and accumulation effect of water absorbing humic acid. The basis for development of management strategies for improvement of soil and crop production in semi-arid areas would be formed.

\section{ACKNOWLEDGEMENTS}

The authors acknowledge financial supports from National natural Science foundation project of China 'The study of water storage and preservation, and ecological mechanism of Water-saving material' (number 31160267), the Special Scientific Research Fund of Agricultural Public Welfare Profession of China (number 201003053-4) and Inner Mongolia natural foundation project (number 2012MS0322).

Special thanks is also given to reviewers.

\section{REFERENCES}

[1] Cao Yuan-bo, Yu Bai-tian, Wei Ting-ting et al, 2014.The Properties of Two Kings of Super Absorbent Ploymer and Its Application.Journal of Soil and Water Conservation, Vol.28No.4,283-288.

[2] Shilong Piao, Philippe Ciais, Yao Huang et al, 2010. The impacts of climate change on water resources and agriculture in China.Nature, 09364.

[3] R.D.Misra. Deficit Irrigation for Reducing Agricultural Water Use. G.B. Pant University of Agriculture \& Technology, Pantnagar.

[4] H. Andry, T. Yamamoto, T. Irie et al, 2009. Water retention, hydraulic conductivity of hydrophilic polymers in sandy soil as 
affected by temperat ure and water quality. Journal of Hydrology 373 (2009) 177-183.

[5] Shengtao Xu, Lei Zhang, Neil B. McLaughlin et al,2015. Effect of synthetic and natural water absorbing soil amendment soil physical properties under potato production in a semi-arid region. Soil \& Tillage Research 148 (2015) 31-39.

[6] M. Robiul Islam, Xuzhang Xue, Sishuai Mao et al, 2011. Superabsorbent polymers (SAP) enhance efficient and eco-friendly production of corn (Zea mays L.) in drought affected areas of northern China. African Journal of Biotechnology Vol. 10(24), 4887-4894.

[7] Mohammad Sayyari and Fardin Ghanbari, 2012. Effects of Super Absorbent Polymer A200 on the Growth, Yield and Some Physiological Responses in Sweet Pepper(Capsicum Annuum L.) Under Various Irrigation Regimes. International Journal of Agricultural and Food Research Vol. 1 No.1, 1-11.
[8] Felora Rafiei, Gorban Nourmohammadi, Rajab Chokan et al, 2013. Investigation of superabsorbent polymer usage on maize under water stress. Global Journal of Medicinal Plant Research, 1(1): 8287, 2013.

[9] Leila Keshavarz and Hasan Farahbakhsh, 2012.Effect of Superabsorbent on physio-morpbent onphysio-morphological traits and forage yield of millet(Pennisetum Americanuml.) under different irrigation treatments. International Journal of Plant, Animal and Environmental Sciences. Vol 2,149-156.

[10] Mao Jin-zhu. Reserch of Effects and Machanism of Supperabsorbent Ploymer on Water-Fertilizer Efficiency of Summer Corn and Winter Wheat Rotation.Beijing: China Agicult ural University, 2013. (In Chinese)

[11] Wang Xu-yu and Wang Yue-xin, 2014. Effects of Application Sodium Humate and the Water Retaining Agent on the Growth and Quality of Lettuce. Humic acid.1:19-22. (In Chinese). 